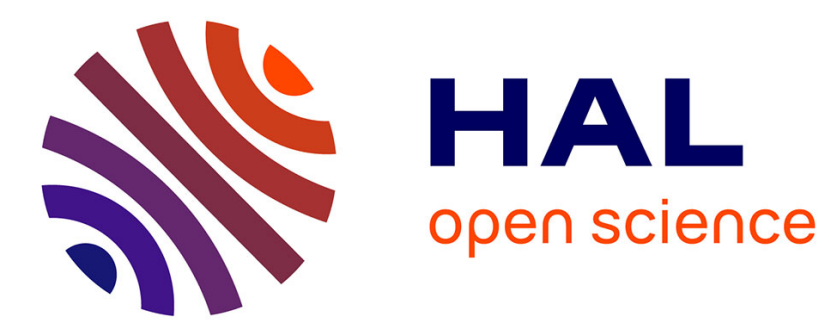

\title{
Mass-settlement of the Indian ocean black-tip grouper Epinephelus oceanicus (Lacepède, 1802) in a shallow volcanic habitat following a tropical storm Mathieu Pinault, Jean-Pascal Quod, René Galzin
}

\section{- To cite this version:}

Mathieu Pinault, Jean-Pascal Quod, René Galzin. Mass-settlement of the Indian ocean black-tip grouper Epinephelus oceanicus (Lacepède, 1802) in a shallow volcanic habitat following a tropical storm. Environmental Biology of Fishes, 2015, 98 (2), pp.705-711. 10.1007/s10641-014-0303-2 . hal01306707

\section{HAL Id: hal-01306707 \\ https://hal.univ-reunion.fr/hal-01306707}

Submitted on 26 Apr 2016

HAL is a multi-disciplinary open access archive for the deposit and dissemination of scientific research documents, whether they are published or not. The documents may come from teaching and research institutions in France or abroad, or from public or private research centers.
L'archive ouverte pluridisciplinaire HAL, est destinée au dépôt et à la diffusion de documents scientifiques de niveau recherche, publiés ou non, émanant des établissements d'enseignement et de recherche français ou étrangers, des laboratoires publics ou privés. 


\title{
Mass-settlement of the Indian ocean black-tip grouper Epinephelus oceanicus (Lacepède, 1802) in a shallow volcanic habitat following a tropical storm
}

\author{
Mathieu Pinault • Jean-Pascal Quod • René Galzin
}

\begin{abstract}
The active selection of recent volcanic habitats by juvenile fish following a cyclone could explain the unusual mass-settlement of the Indian Ocean blacktip grouper Epinephelus oceanicus observed on 25 May 2006, few weeks after tropical storm Diwa on the latest lava flows of the Piton de la Fournaise volcano at Reunion Island. Following a cyclonic depression, shallow underwater habitats are devoid of resident fishes, including predators, favouring juvenile fish survival. Otherwise, the recent origin of the volcanic habitats, which vary in age, could facilitate the spatial segregation of adult and juvenile fish on the lava flows, reducing intraspecific competition and adult aggression toward juveniles. Regional characteristics of larval recruitment could also contribute to the infrequency of the described
\end{abstract}

M. Pinault $(\bowtie) \cdot$ R. Galzin

USR 3278 CNRS-EPHE, CRIOBE \& CBETM, University of

Perpignan,

Perpignan 66860, France

e-mail: math.pinault@gmail.com

M. Pinault

Laboratory of Marine Ecology (ECOMAR), University of

Reunion Island,

FRE3560 INEE-CNRS, 15 Avenue René Cassin, BP 7151, 97715 Saint-Denis Reunion Island, France

J.-P. Quod

Agency for Marine Research and Exploitation (ARVAM),

Cyroi, La Technopole, 2 rue Maxime Rivière,

97490 Sainte-Clotilde Reunion Island, France

R. Galzin

Laboratory of Excellence 'CORAIL',

BP 1013, Moorea 98729, French Polynesia event; the isolated situation of the island would be expected to result in an average density of fish postlarvae $0.25 \%$ to $1 \%$ of that seen on some reefs in the Pacific. The supposed origin of juvenile groupers in the neighbouring island of Mauritius should encourage Reunionese managers to look beyond their own jurisdictions to adopt a collaborative approach to conservation of the entire connected network.

Keywords Cyclone $\cdot$ Volcanic habitat $\cdot$ Post-larval recruitment $\cdot$ Spatial segregation $\cdot$ Habitat selection . Connectivity

\section{Introduction}

Several studies have shown that tropical and subtropical reef fish post-larvae settlement occurs mostly in summer (Dufour et al. 1996; Durville et al. 2002; Pinault 2013). Some authors have also reported recruitment events related to the new moon period, with fish post-larvae migrating on dark nights, which limit predation (Dufour and Galzin 1993; Letourneur 1996; Durville et al. 2002). Many species of groupers present irregular and relatively low fecundity, heavily influenced by environmental variables (Durville et al. 2002). In Reunion Island, several studies have described the effect of cyclones on pelagic larval dispersal (Crochelet et al. 2013) and on grouper post-larvae density in coral reef areas (Letourneur et al. 1998; Chabanet et al. 2005). Other recent works carried out on lava flows of different ages of the Piton de la Fournaise volcano (PF), on the 
southeast coast, have described the early stages of ecological succession in several communities (Bollard et al. 2013; Pinault et al. 2013b, 2014). It appeared that groupers preferentially settled on the most recent lava flows. However, no study has been conducted of the cumulative effects of cyclones and age of habitat on density and spatial segregation of grouper post-larvae during settlement. The Indian Ocean blacktip grouper Epinephelus oceanicus (Lacepède, 1802) is a small [maximum total length (TL): $40 \mathrm{~cm}$ ] Indian Ocean serranid subspecies of the blacktip grouper E. fasciatus (Forsskål, 1775) (Gill and Kemp 2002) common in Reunion, but with numbers declining over the past 30 years (Fricke et al. 2009). It feeds night and day, mostly on fish and some crustaceans (Harmelin-Vivien and Bouchon 1976). The first Reunionese mass settlement of this species was observed on recent lava flows of the PF several weeks after the passage of tropical storm Diwa. The aim of this work is to describe and discuss cumulative effects of cyclone and age of habitat as possible mechanism of observed unusual mass settlement.

\section{Material and methods}

Reunion Island is located $690 \mathrm{~km}$ east of Madagascar $\left(21^{\circ} 06^{\prime} \mathrm{S} ; 5^{\circ} 33^{\prime} \mathrm{E}\right)$ in the Mascarene Archipelago. Its climate is humid tropical with a warm rainy season from November to April (austral summer) marked by a tropical storm or cyclone of varying intensity, on average, every two years (Soler et al. 1997). The waves generated during these events, often from the northeast (56\%) or northwest (38\%), do not affect the entire coastline with equal intensity. While the coastal communities of the northern half of the island are subject to seasonal disturbances, those of the southern half are rarely affected by cyclonic events (Soler et al. 1997). The southern region is nevertheless exposed to trade winds and is characterized by regular sea swells, which can sometimes be strong, particularly during the austral winter (Pinault et al. 2013b). The west coast of the island is highly urbanized, with discontinuous stretches of fringing reef extending over $25 \mathrm{~km}$. In contrast, the southeast coast, marked by activity of the PF, is sparsely inhabited. Most of the recent PF eruptions (2002, 2004, 2005, 2007) have been from vents inside the walls of the current caldera at different elevations along the rift zone, but three of the past four large- volume deep-seated eruptions (1977, 1986, 1998) had at least one vent located outside of the caldera rim, along an extension of the intracaldera rift zone (Vigouroux et al. 2009).

On 25 May 2006, between 09:00 and 16:00 h, marine scientists of the Agency for Marine Research and Exploitation explored shallow habitats on four PF lava flows (1977, 2002, 2004, and 2005) (Fig. 1). The fieldwork took place 11 weeks after tropical storm Diwa (4 to 7 March 2006), which was characterized by an unusual austral swell from the southwest, reaching a $10 \mathrm{~m}$ surge on the most exposed parts of the island, that heavily impacted the entire coastline of the study area with the same intensity. The survey was conducted $8 \mathrm{wk}$ after the first new moon following the storm. It was part of a biannual monitoring program (November and May) of shallow underwater communities of the volcano initiated in 2002 and continued until 2014. Because of the high physical relief of the substrate, the point-count, stationary visual-census method (Bortone et al. 1989) whereby a scuba diver takes up a position at the centre of an imaginary circle with a radius of $5.6 \mathrm{~m}\left(100 \mathrm{~m}^{2}\right)$, was implemented. On each site (lava flows of differing age), two trained divers carried out a total of six pointcounts, recording species, densities, and estimated TL of individual fish over a depth range from 10 to $15 \mathrm{~m}$ due to steep slopes on underwater lava flows, introducing an increase in depth between the top and the bottom of point-count diameters. Underwater visual-census techniques are non-destructive, fishery-independent methods and therefore superior to destructive collection techniques, especially in sensitive areas. They require little post-processing, whereas collections take many hours to complete. Visual census, however, has a tendency to produce an underestimation the smallbodied, nocturnal, and cave species of the fish fauna (Willis 2001). It is thus possible that densities reported in this survey were underestimated. Conversely, according to Edgar et al. (2004) visual estimates of fish length are on average $7 \%$ greater than measured lengths. It is thus possible that reported TL were overestimated. The field notes were integrated into a numerical database before being analyzed. Average population densities and TL were compared among sites by non-parametric Kruskal-Wallis analyses followed by Dunn post-hoc tests due to the nonnormality and heteroscedasticity of the data. Statistical significance was set at $p \leq 0.05$. All 


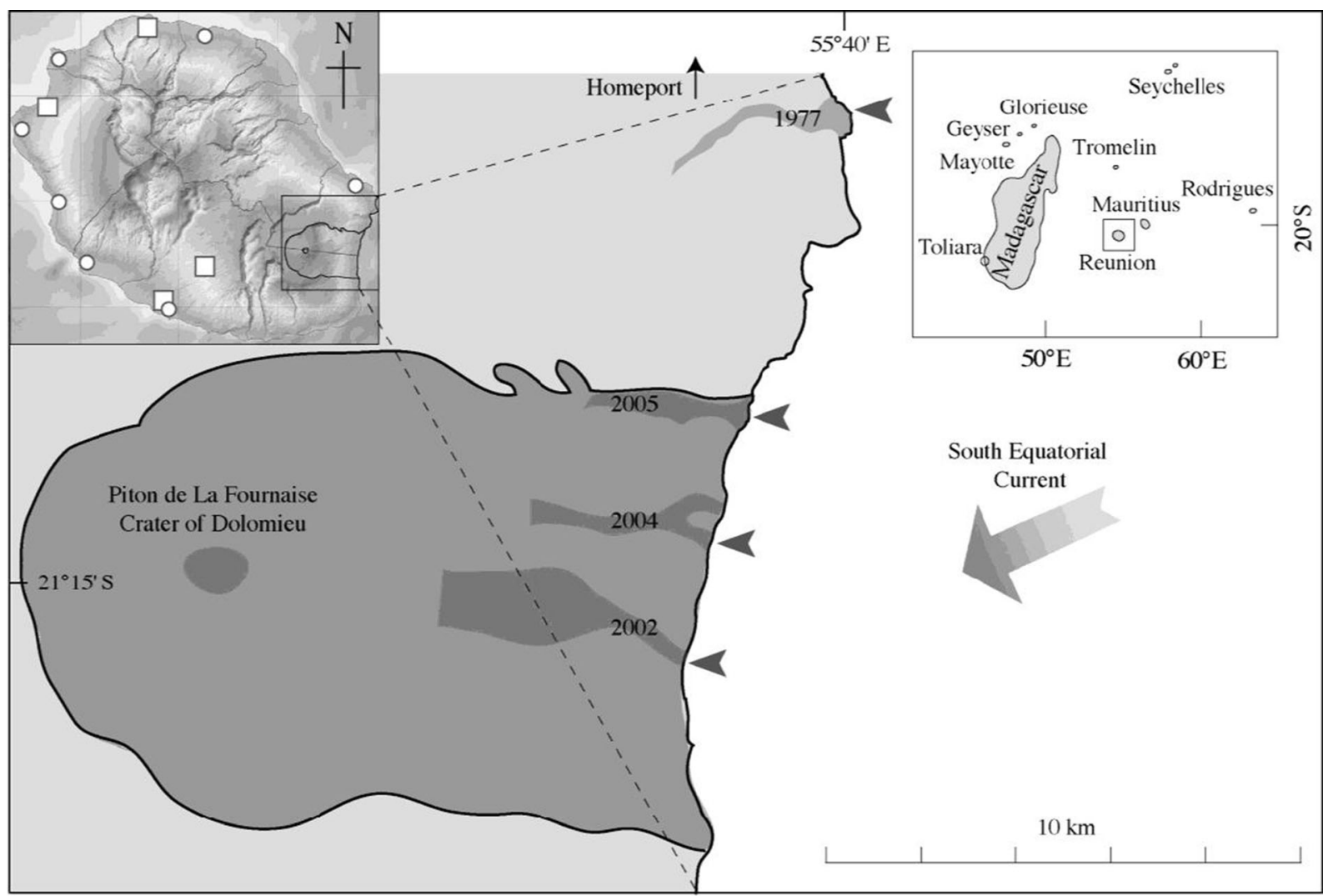

Fig. 1 Location of the 4 sampling sites along the slopes of the Piton de la Fournaise, Reunion Island, south-western Indian Ocean $\square$, outside volcanic enclosure; $\square$, inside volcanic enclosure; lava flows and crater; $<$, sampling stations; $\square$, major population centres (>60 000 inhabitants);, ports statistical analyses were performed with R (R development Core Team 2008).

\section{Results}

Epinephelus oceanicus was observed on all surveyed lava flows except the 1977 site. Mean densities were $3.5 \pm 0.8$ (SD) ind. $100 \mathrm{~m}^{-2}$ at the 2002 site, $85.0 \pm$ 44.2 ind. $100 \mathrm{~m}^{-2}$ at the 2004 site, and $47.7 \pm 20.7$ ind. $100 \mathrm{~m}^{-2}$ at the 2005 site (Fig 2A). The mean density at the 2002 site was significantly lower than those at the 2004 and 2005 sites, which were not significantly different (Kruskal-Wallis $p=0.002$ ). Mean total length of individual fish was $18.9 \pm 1.9 \mathrm{~cm}$ at the 2002 site, $10.5 \pm 0.5 \mathrm{~cm}$ at the 2004 site, and $11.0 \pm$ $1.2 \mathrm{~cm}$ at the 2005 site (Fig 2B). The mean total length at the 2002 site was significantly greater than at the
2004 and 2005 sites, which were not significantly different (Kruskal-Wallis $p=0.003$ ).

The social behaviour of the fish also differed among sites. The groupers observed at the 2004 and 2005 sites were gregarious, distributed in loose schools under overhangs and tolerating the sympatric presence of juvenile carnivore species such as the crown squirrelfish Sargocentron diadema (Lacepède, 1802), the blotcheye soldierfish Myripristis berndti (Jordan and Evermann, 1903), the striped large-eye bream Gnathodentex aureolineatus (Lacepède, 1802), and the common bluestripe snapper Lutjanus kasmira (Forsskål, 1775) (Fig 3A). Conversely, those observed at the 2002 site were isolated and territorial. Grouper tendency to hide from divers also showed specificity. While groupers at the 2002 site were wary, those at the 2004 and 2005 sites were curious and incautious (Fig. 3B). 
Fig. 2 Box-plots of the values measured during the survey on 25 May 2006 on the 2002, 2004, and 2005 lava flows of the Piton de la Fournaise, Reunion Island. A, Density of Epinephelus oceanicus (ind. $100 \mathrm{~m}^{-2}$ ); B, Mean total length of individual fish $(\mathrm{cm})$. Kruskal-Walli test, "a" values were significantly higher than "b" values. Same letters were not significantly different
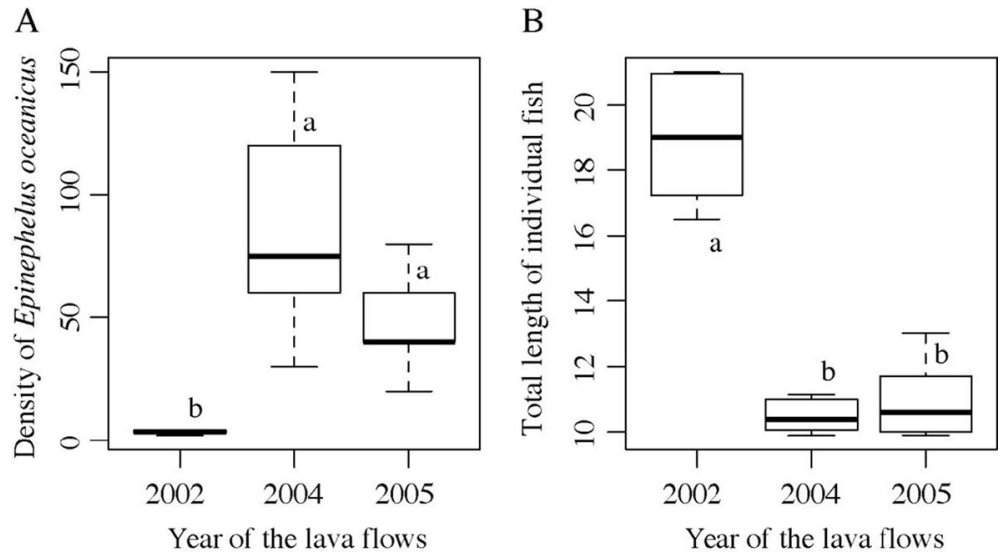

No other mass-settlement event had occurred during the 13 years of investigation, either on the PF lava flows

or on other Reunion coastal areas studied in numerous regional science programs (Pinault et al. 2013a).
Fig. 3 Mass-settlement of Epinephelus oceanicus photographed on 25 May 2006 on the 2004 lava flow of the Piton de la Fournaise, Reunion Island. A, overview; B, detail (Photographs: Jean-Pascal Quod)
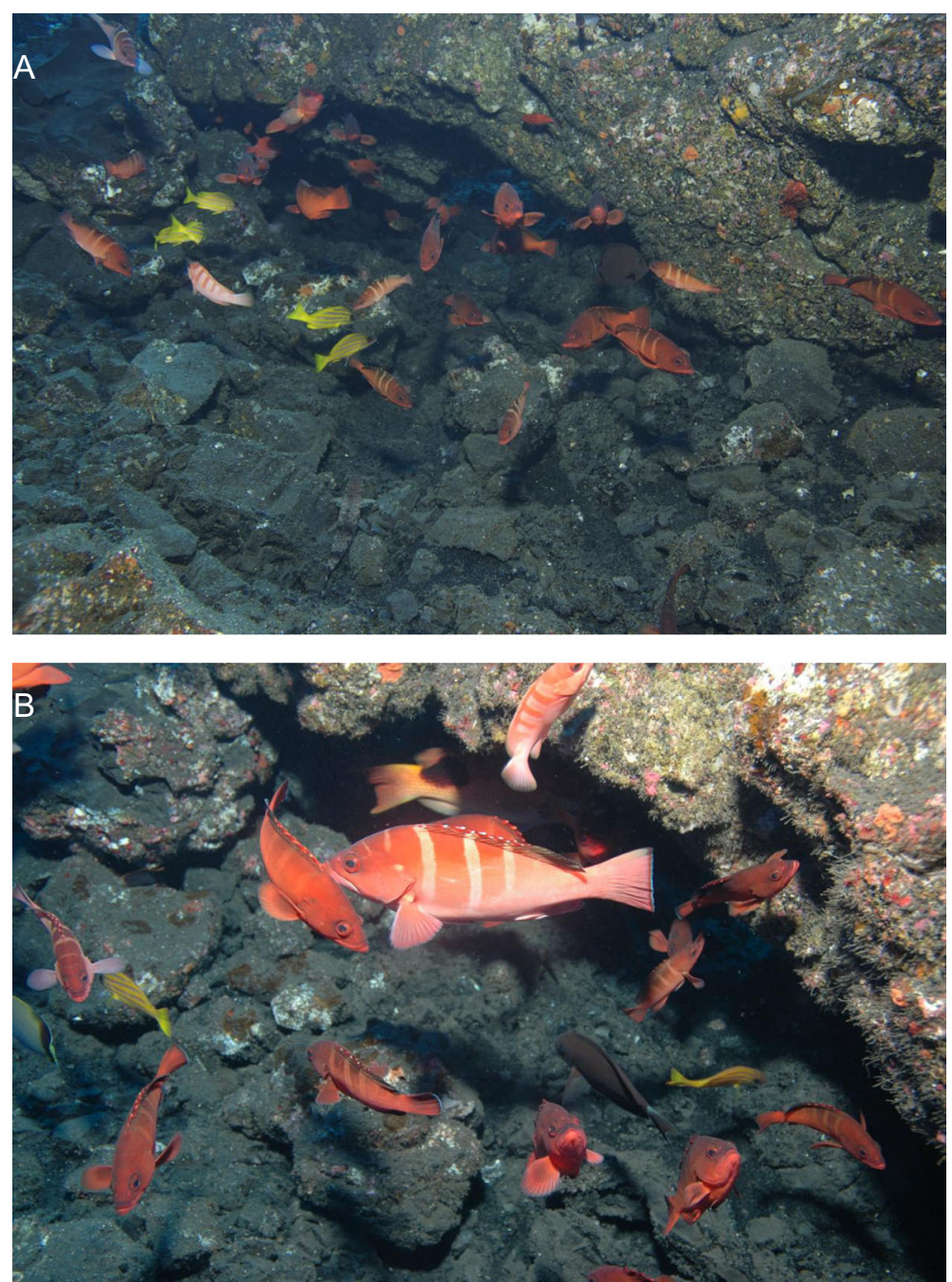


\section{Discussion}

In a study of coral reef fishes following a cyclone, Walsh (1983) stated that the shallow reef flat was devoid of resident fish, including predators, while deeper areas contained fish that had moved from shallower water. Fish recolonization of evacuated areas began shortly after the storm, and within 16 months many areas had regained their pre-storm condition, although large numbers of individuals remained in the new locations. This transient decrease in predator density could favour the colonization of storm-impacted sites by fish post-larvae, which are vulnerable to predation. In a study of reef fish post-larvae captured just before settlement in Reunion, Durville (2002) estimated the recruitment length of Serranidae to be 3.0 to $4.0 \mathrm{~cm}$. Following the growth curve of E. oceanicus offered by Rafail (1972), the TL of the fish 2.0 to 2.5 months after recruitment can be estimated at 7 to $10 \mathrm{~cm}$. The majority of the fish observed at the 2004 and 2005 sites fell into that length range. This supports the hypothesis of synchronisation of recruitment with the passage of tropical storm Diwa. A study by Mishina et al. (2006) on the sister species E. fasciatus considered that the spawning period was closely dependent on the water temperature. Shapiro (1987) estimated that this period extended from September to February in New Caledonia. The cyclone Diwa would thus produced at the end of spawning season, providing an opportunity for post-larvae hatched several weeks earlier to colonize stormimpacted habitats.

The mass-settlement reported here was not observed to have occurred evenly across sites; the most recent flows were the most heavily colonized by juveniles. Differences in fish behaviours may be the result of different stages of maturity among surveyed populations. Myers (1999) estimated that sexual maturity in the species was reached at $T L \geq 19.5 \mathrm{~cm}$. It appears that the population observed on the 2002 site consisted mostly of adult and pre-adult fish, at or near the minimum length of sexual maturity. Conversely, the populations observed at the 2004 and 2005 sites showed only immature fish, $86 \%$ of which were of $\mathrm{TL} \leq 11 \mathrm{~cm}$. Robertson et al. (1979) documented habitat segregation of adults and juveniles in five species of Indian Ocean reef fishes and suggested that differential habitat use limited intraspecific competition and adult aggression toward juveniles. The few studies of reef fish assemblages in shallow volcanic habitats have reported juvenile densities to be highest on the youngest lava flows, where adult densities were relatively low (Godwin and Kosaki 1989). Durville (unpublished data) noted that 50 days after cessation of the PF flow of August 2004, outside the recruitment period of most reef species, $95 \%$ of the fish abundance consisted of juveniles (mostly Anthiinae). This phenomenon also showed a strong spatial segregation, as juveniles accounted for only $8 \%$ of the total abundance measured at a nearby site located outside the 2004 flow. However, in the absence of further disturbance, this trend subsided to a uniform among-site proportion of juveniles within 5 months of cessation of the flow.

Odum (1969) showed that in the developmental stage of ecological succession, organisms tend to be small with simple life histories and rapid rates of reproduction. As the ecosystem develops, the selective advantage shifts to larger organisms, which have greater storage capacities and more complex life histories and are better adapted to exploiting seasonal or periodic releases of nutrients and other resources. Hence, the ecosystem gains complexity and becomes more resistant, gaining system-wide buffers against extrinsic and intrinsic perturbations. In addition, disturbed ecosystems are often characterized by a reduction in the length of food chains that promotes the establishment of juveniles and opportunistic species (Caswell and Cohen 1991). The more intense ecological disturbances suffered by the most recent sites (1-2 years) could thus indirectly promote the survival of juvenile fish, while the greater resistance of the older ecosystems ( $>29$ years) allowed conservation of their ecological structure and therefore their predation pressure on juveniles. The mean values observed by Pinault (unpublished data) in October 2012, on a non-impacted prehistoric PF flow few miles north of the study area (density $=0.5 \pm 0.6$ ind. $100 \mathrm{~m}^{-2}$; TL $=$ $16.5 \pm 2.1 \mathrm{~cm}$ ), quite similar to those measured at the 2002 site after tropical storm Diwa, support this possibility.

Regional characteristics of larval recruitment could also contribute to the infrequency of the described event. The isolated situation of the island would tend to produce an average density of the overall fish post-larvae from $0.25 \%$ to $1 \%$ of that seen on some reefs in the Pacific (Durville et al. 2002). Otherwise, the origin of the E. oceanicus larvae involved in this mass-settlement event remains unclear. Although no studies have been conducted on larval stage duration or growth rate of E. oceanicus larvae, Crochelet et al. (2013), working 
on E. merra, suggested that, for small grouper species, these factors are consistent with allo-recruitment from Mauritius, located about $200 \mathrm{~km}$ northeast of Reunion Island, where E. oceanicus was previously recorded (Fricke et al. 2009). The South Equatorial Current, which bathes these two neighbouring islands, runs northeast to southwest (Fig. 1), placing the coral reefs of the west coast of Reunion downstream of the general current patterns and supporting the idea that the fish came from Mauritius (Crochelet et al. 2013). This long migration in the pelagic environment by grouper larvae in a scarce recruitment context could have a negative effect on the survival probability of individual fish (straying off course, predation). If the intrinsic characteristics of recent volcanic habitats justify their conservation, managers of the island must look beyond their own jurisdictions and collaborate to protect the connected network as a whole, including Mauritius.

Acknowledgments We are grateful for the helpful critique by anonymous referees who read an earlier draft of this study. This research was conducted with the approval of the Grice (Interprofessional Working Group on Ethics Committees for animal experimentation/Groupe de Réflexion Interprofessionnel sur les Comités d'Ethique appliquée à l'expérimentation animale).

\section{References}

Bollard S, Pinault M, Quod JP, Boissin E, Hemery L, Conand C (2013) Biodiversity of echinoderms on underwater lava flows with different ages, from the piton de La Fournaise (reunion island, Indian ocean). Cah Biol Mar 54:491-497

Bortone SA, Kimmel JJ, Bundrick CM (1989) A comparison of three methods for visually assessing reef fish communities: time and area compensated. North Gulf Sci 10:85-96

Caswell H, Cohen JE (1991) Communities in patchy environments: a model of disturbance, competition, and heterogeneity. In: Kolasa J, Pickett ST (eds) Ecological Heterogeneity, New York, NY: Springer-Verlag, p 97-122

Chabanet P, Moyne-Picard M, Pothin K (2005) Cyclones as masssettlement vehicles for groupers. Coral Reefs 24:138

Crochelet E, Chabanet P, Pothin K, Lagabrielle E, Roberts J, Pennober G, Lecompte-Finiger R, Petit M (2013) Validation of a fish larvae dispersal model with otolith data in the western Indian ocean and implications for marine spatial planning in data-poor regions. Ocean Coast Manag $86: 13-21$

Dufour V, Galzin R (1993) Colonization patterns of reef fish larvae to the lagoon at Moorea island, french Polynesia. Mar Ecol Prog Ser 102:143-143

Dufour V, Riclet E, Lo-Yat A (1996) Colonization of reef fishes at Moorea island, French Polynesia: temporal and spatial variation of the larval flux. Marshes Freshw Res 47:413-422
Durville P, Bosc P, Galzin R, Conand C (2002) Colonization of a fringing reef of reunion island by coral fish larvae. Acta Oceanol Sin 25:23-30

Edgar GJ, Barrett NS, Morton AJ (2004) Biases associated with the use of underwater visual census techniques to quantify the density and size-structure of fish populations. J Exp Mar Biol Ecol 308:269-290

Fricke R, Mulochau T, Durville P, Chabanet P, Tessier E, Letourneur Y (2009) Annotated checklist of the fish species (Pisces) of La Réunion, including a Red List of threatened and declining species. Stuttg Beitr Naturkd A 2:1-168

Gill AC, Kemp JM (2002) Widespread indo-pacific shore-fish species: a challenge for taxonomists, biogeographers, ecologists, and fishery and conservation managers. Environ Biol Fish 65:165-174

Godwin JR, Kosaki RK (1989) Reef fish assemblages on submerged lava flows of three different ages. Pac Sci 43:289-301

Harmelin-Vivien ML, Bouchon C (1976) Feeding behavior of some carnivorous fishes (Serranidae and Scorpaenidae) from Tulear (Madagascar). Mar Biol 37:329-340

Letourneur Y (1996) Dynamics of fish communities on reunion fringing reefs, Indian Ocean. II. Patterns of temporal fluctuations. J Exp Mar Biol Ecol 195:31-52

Letourneur Y, Chabanet P, Vigliola L, Harmelin-Vivien M (1998) Mass-settlement and post-settlement mortality of Epinephelus merra (Pisces: Serranidae) on Réunion coral reefs. J Mar Biol Assoc UK 78:307-319

Mishina H, Gonzares B, Pagaliawan H, Moteki M, Kohno H (2006) Reproductive biology of blacktip grouper, Epinephelus fasciatus, in Sulu Sea, Philippines. Mer 44:23-31

Myers RF (1999) Micronesian reef fishes: a comprehensive guide to the coral reef fishes of Micronesia, 3rd revised and expanded edition. Coral Graphics, Barrigada

Odum EP (1969) The strategy of ecosystem development. Science $164: 262-270$

Pinault M (2013) Évaluation de la fonctionnalité de récifs artificiels à vocation non extractive, dans un contexte d'habitats naturels fragmentés - Côte nord-ouest de l'île de La Réunion. Cybium 37:262

Pinault M, Chabanet P, Loiseau N, Durville P, Galzin R, Quod JP (2013a) Influence des facteurs environnementaux sur la structure des peuplements ichtyologiques côtiers de l'île de La Réunion (Sud-Ouest de l'océan Indien). Cybium 37:95-109

Pinault M, Loiseau N, Chabanet P, Durville P, Magalon H, Quod JP, Galzin R (2013b) Marine fish communities in shallow volcanic habitats. J Fish Biol 82:1821-1847

Pinault M, Bissery C, Gassiole G, Magalon H, Quod JP, Galzin R (2014) Fish community structure in relation to environmental variation in coastal volcanic habitats. J Exp Mar Biol Ecol. doi:10.1016/j.jembe.2014.06.005

R development Core Team (2008) R: a language and environment for statistical computing. R Foundation for Statistical. Computing, Vienna, Austria. http://www.rproject.org

Rafail SZ (1972) A statistical study of length-weight relationship of eight Egyptian fishes. Bull Inst Oceanogr Fish 2:136-156

Robertson DR, Polunin NV, Leighton K (1979) The behavioral ecology of three Indian Ocean surgeonfishes (Acanthurus lineatus, A. leucosternon and Zebrasoma scopas): their feeding strategies, and social and mating systems. Environ Biol Fish 4:125-170 
Shapiro DY (1987) Reproduction in groupers. In: Polovina JY, Ralston S (eds) Tropical snappers and groupers: biology and fisheries management. Westview Press, Boulder, pp 295-327 Soler O, Dumont S, Le Goff G (1997) Atlas climatique de La Réunion. Météo France, Sainte-Clotilde

Vigouroux N, Williams-Jones AE, Wallace P, Staudacher T (2009) The november 2002 eruption of piton de la Fournaise,
Réunion: tracking the pre-eruptive thermal evolution of magma using melt inclusions. Volcanol 71:1077-1089

Walsh WJ (1983) Stability of a coral reef fish community following a catastrophic storm. Coral Reefs 2:49-63

Willis TJ (2001) Visual census methods underestimate density and diversity of cryptic reef fishes. J Fish Biol 59: 1408-1411 